結禁系を核とした肉芽腫による良性胆管狭寉の 1 例 大阪大学大学院臟器制御外科, 大阪労災病院外科* 水島恒和山上裕子* 甲斐康之* 吉川 澄*

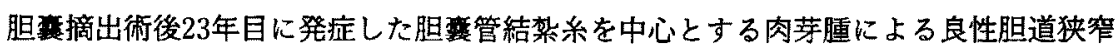

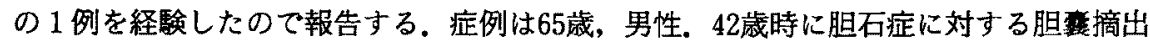
術の既往を有する. 1997年 2 月黄疸，食欲低下にて近医を受診，T.Bil 上昇を認め当科 紹介された，腹部超音波，腹部 CT 検查上末梢胆管の搪張を認め，総胆管右側に腫瘤が 疑われた. 胆道造影では総胆管に $3 \mathrm{~cm}$ の狭窄を認めた. 肝門部胆管癌を疑い開腹手術を 施行した. 開腹所見では径 $1.5 \mathrm{~cm}$ 大の腫揚が総胆管を右後方より王排する形で存在した ため, 肝左葉切除, 胆管切除術を施行し右肝管空腸吻合にて再建した。切除標本でも総 肝管分㞳部右側に $1.5 \times 1.2 \mathrm{~cm}$ の腫瘍を認めたが, 病理組織学的に胆軎管の結禁系を中 心とする肉芽腫と診断された，異物を原因とする良性胆道狭窄の報告は稀であり，文献 的考察を加えて報告する.

索引用語：良性胆道狭害, 術後胆道狭窄

\section{緒言}

胆道狭窄は悪性胆道狭窄と良性胆道狭窄に分類され るが良性胆道狭猚にもさまざまな原因があり，術前に 確定診断を得ることは容易ではない"，われわれは肝 門部胆管癌との鑑別が困難であった胆裹管の結紮系を 中心とする肉芽腫による良性胆道狭窄の1例を経験し たので, 文献的考察を加えて報告する.

$$
\text { 症例 }
$$

症例：65歳, 男性.

主訴：黄疸, 食欲低下.

家族歴：特記すべきことなし。

既往歴：38歳時, 虫垂炎にて虫垂切除術．42歳時, 胆石症にて開腹胆毫摘出術.

現病歴：1997年 2 月初旬より食欲低下があった。 2 月10日, 眼球結膜の黄染を自覚し近医を受診した。血 液検査にて T. Bil の上昇を指摘され, 黄疸の精査加療 目的にて当科に紹介された。

入院時現症: 体温 $36.8^{\circ} \mathrm{C}$, 経過中 $38^{\circ} \mathrm{C}$ 超える発熱 を認めず. 身長 $160 \mathrm{~cm}$, 体重 $58 \mathrm{~kg}, 10$ 日間て $3 \mathrm{~kg}$ の体 重滅少を認めた。眼瞼結膜, 眼球結膜黄染著明・心音・

2003年 1 月 17 日受付 2003 年 5 月 20 日採用

〈所属施設住所〉

亍565-0871 吹田市山田丘 2-2 E 1
呼吸音正常・腹部平坦，軟．腫㾕など触知せず，右助 骨弓下，右下腹部に手術痕を認めた。

入院時検查所見 : $\mathrm{RBC} 483$ 万, $\mathrm{Hb} 16.2 \mathrm{~g} / \mathrm{dl}, \mathrm{Ht}$ 48.4\%, WBC 5.900, Plt 17.5万, AST 82U/L, ALT 100U/L, T. Bil $16.1 \mathrm{mg} / \mathrm{dl}, \gamma$ GTP $439 \mathrm{U} / \mathrm{L}$, ALP 449 U/L, LAP 240U/L, LDH 317U/L, CPK 154U/L, BUN $11 \mathrm{mg} / \mathrm{dl}$, Cr $0.8 \mathrm{mg} / \mathrm{dl}$, PT $100 \%$, APTT 27.7 s, ICGR15 20\%, CEA 2.3ng/ml, CA19-9 748U $/ \mathrm{ml}$. T. Bil, 胆道系酵素の上昇掞よびAST, AIT の軽 度上昇を䜑めた。腫湟マーカーでは CA19-9 の上昇を 認めた。

腹部超音波：総胆管右側に腫瘤の存在が疑われ，腫 瘤より末梢の胆管拡張を認めた（図 1 )。

腹部 CT：肝門部より末梢の胆管拡張を認めた。肝 左葉外側区域より PTCD を施行し, 左肝管より狭鿽部 を越え総胆管へPTCDチューブを挿入した，PTCD チューブから行った胆道造影上右肝管から末梢が造影 されなかったため,再度透視下にPTCD チューブ先端 を右肝管へと誘導した。

ERCP：PTCDチューブからの胆道造影を併用し た ERCP では総胆管から左右肝管分岐部に約 $3 \mathrm{~cm} の$ 狭窄を認めた（図 2 ).

腹部 CT：PTCD からの胆道造影を併用した腹部 $\mathrm{CT}$ では総胆管上部に径 $1.5 \times 1 \mathrm{~cm}$ 大の腫演を認めた 


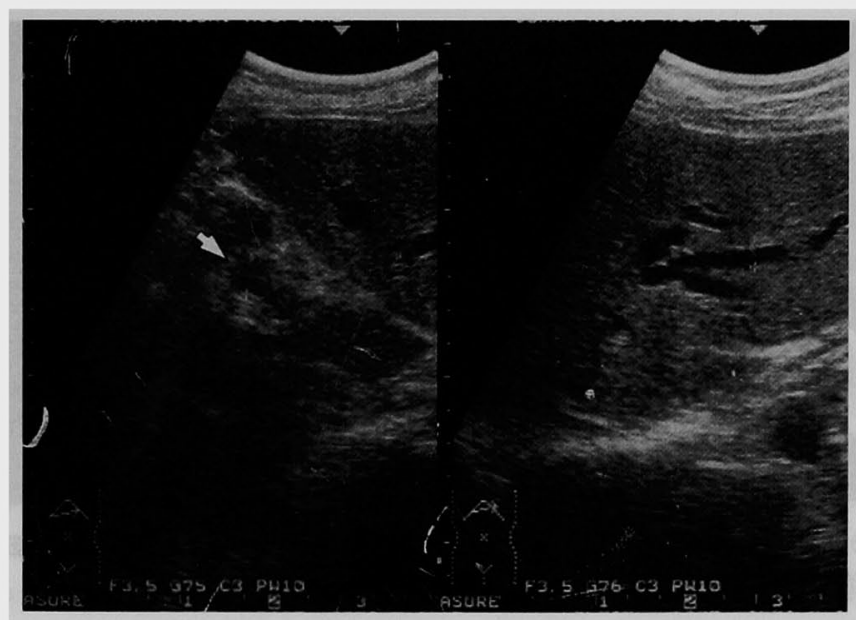

a

b

図 1 腹部超音波検查：（a）総胆管右側に腫瘤像（矢印）を認めた。 (b) 腫箇より末梢の胆管拡張を認めた.

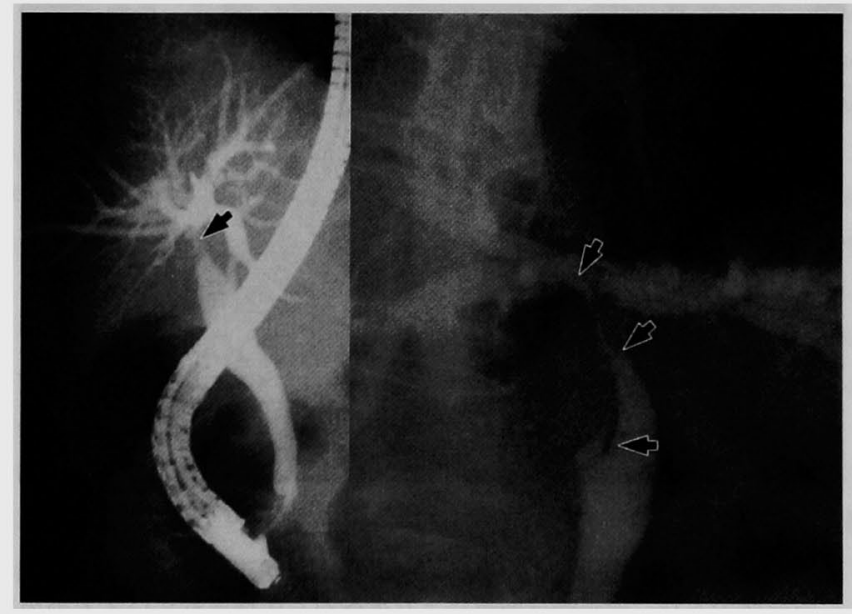

図 2 胆道造影検查：総胆管から左右肝管分岐部に約 $3 \mathrm{~cm}$ の狭窄 （矢印）を認めた。

(図 3 ).

以上の所見より，肝門部胆管癌を疑い開腹手術を施 行した。

術中所見：開腹所見では径 $1.5 \mathrm{~cm}$ 大の腫瘍が総胆 管を右後方より圧排する形で存在したが, 肝実質, 肝 内胆管などへの浸潤は認めなかった，胆管断端陰性確 保のためにはいずれかの肝葉切除が必要と考えられた が, 術後の残肝機能を考慮し肝右葉を温存, 肝左葉切 除, 胆管切除術を施行した. 術中迅速病理組織検查に て断端陰性を確認後, 右肝管空腸吻合にて再建した。
切除標本：総肝管分岐部右側に $1.5 \times 1.2 \mathrm{~cm}$ の腫瘍 を認めた（図4).

病理組織学的所見：腫瘍は炎症細胞, 線維芽細胞な どからなる肉芽腫であり，総胆管は腫場により外側か ら圧排されているものの粘膜面は保たれていた，腫場 の中心には無構造で核を有さない胆鸾摘出術の際の縫 合系と思われる像を認めた（図５）。

考察

良性胆道狭窄とは悪性疾患以外の原因で発症する胆 道狭窑のすべての総称でその病因は多㞳にわたり病態 


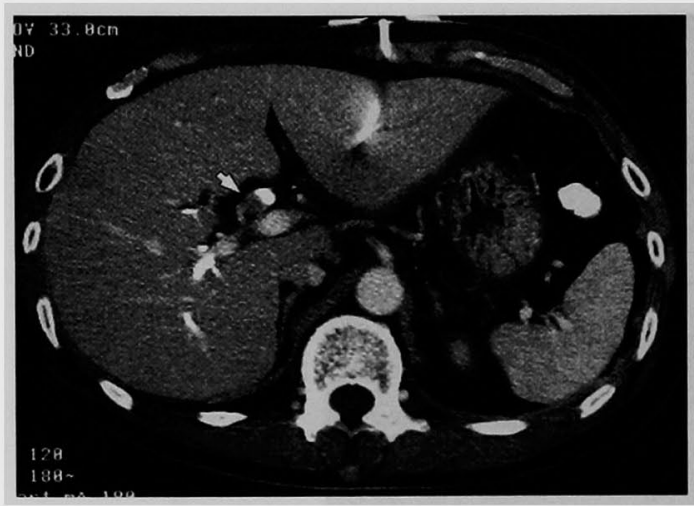

図 3 腹部 CT : PTCD からの胆道造影を併用した腹部 CT では総胆管上部に径 $1.5 \times 1 \mathrm{~cm}$ 大の腫瘍 (矢印) を 認めた。

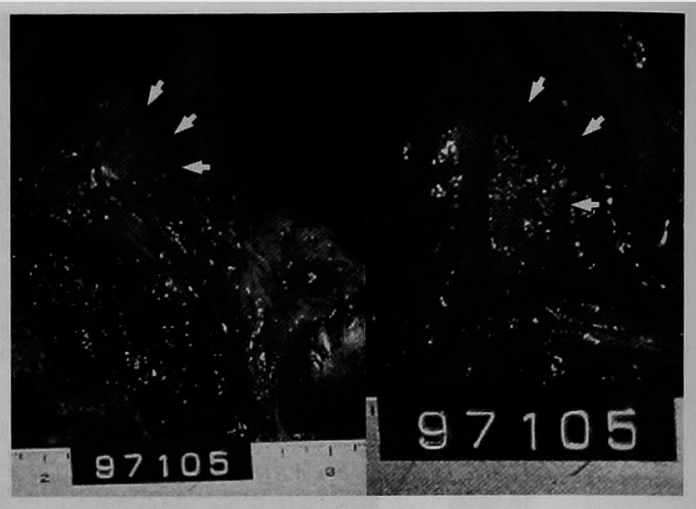

図 4 切除標本：総肝管分岐部右側に $1.5 \times 1.2 \mathrm{~cm}$ の尰 瘍（矢印）を認めた。

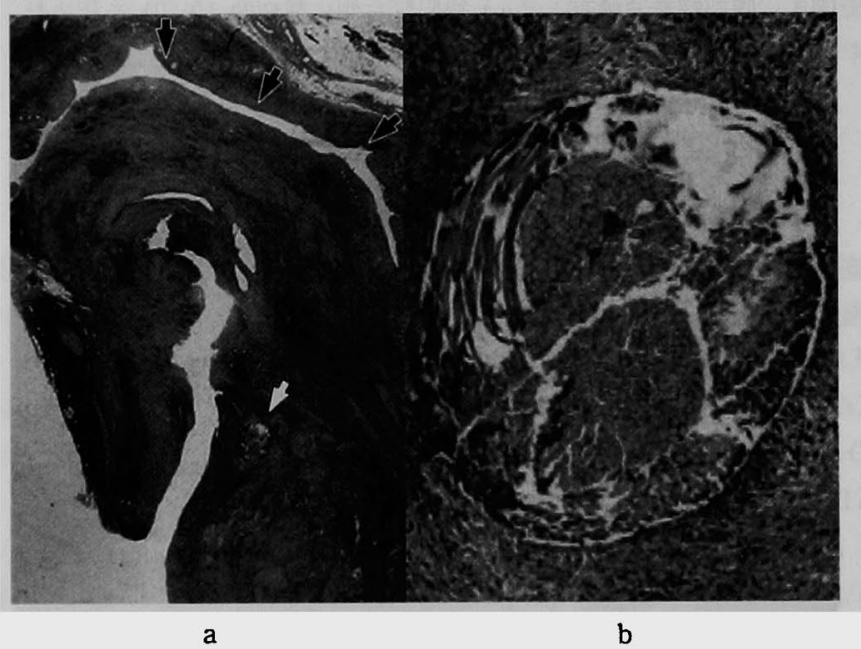

図 5 病理組織学的所見：腫㾇は炎症細胞，線維芽細胞などからなる 肉芽腫であり，総胆管は腫瘍により外側から压排されているものの 粘膜面は保たれていた (黒矢印)。腫瘍の中心には無構造で核を有さ ない胆重摘出術の際の縫合糸と思われる像 (白知印)を認めた（a： HE 染色 $\times 20$, b : HE 染色 $\times 200)$.

は複雑である"．画像上良悪性の鑑別が困難であるこ とも多く治療法の選択に難渋する場合も多い.

良性胆道狭穾は乳頭部狭窄, 先天性胆道拡張症や肝 内結石症に伴う非手術性胆道狭窄と開腹手術に関連し た術後胆道狭窄に分類されるが, 術後胆道狭窄は良性 胆道狭窄の約 $20 \%$ を占めるとされている ${ }^{23)}$. 術後胆道 狭窄には胆管消化管吻合部狭窄（吻合部狭窄）や術中 胆道損傷, 術中剥離操作による胆管壁の虚血, 胆汁漏 出に伴う炎症による狭窝に加えて腹部手術後に生じる
原因不明の㾗痕性狭窄も含まれる。術後胆道狭窄の 80 $\%$ 以上が術後 1 年以内に, $94 \% か ゙$ 術後 5 年以内に発症 するとされているが4)5)，術後10年以上の長期間を経て 発症する例も存在する ${ }^{6)}$. 初発症状としては閉塞性黄 疸や胆管炎症状が多いが，無症状で胆管拡張を指摘さ れている症例もあることから軽度の胆道狭窄があって も顕性化せず経過する症例も存在するのではないかと 考えられる7). 本症例も開腹胆襄摘出術から23年を経 てからの発症であるが，胆道狭窄の原因が肉芽腫によ 
るものであることから発症以前より軽度の胆道狭窄が 存在した可能性も考えられる。

近年の画像診断技術の進歩により胆道狭窄の診断は 容易になったが，胆管の陰影欠損が認められても良悪 性の鑑別は困難である場合が多い. 経皮経肝胆道鏡 (PTCS) による直視下生検や胆道内超音波検查 (IDUS) による胆管を中心とした水平横断超音波像 が有用であるとする報告もあるが899)、結節浸潤型, 浸 潤型の胆管癌は粘膜表層進展より粘膜下進展を示すこ とが多く,内視鏡下生険ては困難であり, 癌細胞の implantation の危険性もあり, 注意して行うべきである と考えられる7．尰瘤による良性胆道狭窄の報告は胆 管周囲の神経切断による外傷性神経腫によるものや， 止血クリップに対する異物反応による肉芽腫によるも のがある ${ }^{(0) 111}$. 本症例は胆管の結梨系に対する異物 反応による肉芽腫が原因で良性の胆道狭管をきたした と考えられる．良性胆道狭窄といえども放置すれば狭 窄により胆斗うっ滞から慢性胆管炎, 肝硬変, 聞脈圧 亢進症を引き起こす可能性があるため, 血液検查など で胆计うっ滞, 閉塞性黄疸などの所見が認められる場 合には何らかの治療が必要となる．その際には内視鏡 下バルーン搪張や外科的手術が検討されるべきであ る. 良性胆道狭窄症例に対しメタリックステントを用 いて良好な結果を得たという報告もみられるが，良性 疾患に対するメタリックステントの使用に関しては未 だ議論の分かれるところであり慎重な対処が必要であ ると考えられる. 本症例では仮に IDUS や直視下生検 を行ったとしても局所的な悪性病変が存在する可能性 は否定できないため良性の確診を得ることは困難であ る.このような良覀性の鑑別が困難な症例に対しては 悪性を否定できないかきり肝切除にて対処すべきであ ると考えられる12!.

また網系は合成吸収しに比し生体内で異物反応を惹 起しやすいことが知られており，しばしば感染帛，肉芽 腫 ${ }^{(4)}$, 出血 ${ }^{15)}$ な゙の原因となることが報告されている. このような巽物反応予防のためには合成吸収系の使用 等の工夫も有用であると考えられる.

結語

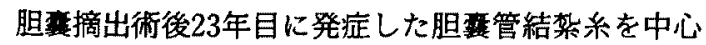
とする肉芽腫による良性胆道狭窄の 1 例を経験したの で報告した。

本論文に関し大阪労災病院臨床病理科, 川野 䍴先生に 御助言を頂きました。

\section{文献}

1) Blumgart LH : Benign Biliary Strictures. Ed by Blumgart LH, Surgery of the Liver and Biliary Tract, Churchill Livingstone, London, 1988, p721-740

2）伊藤 豊, 高野靖悟, 佐藤一雄他: 良性胆道㹨窄 症例の検討. 日臨外会誌 $57: 1065-1071,1996$

3）生駒 明, 田中紘輝, 石崎直樹他：良性胆道狭窄 39例の臨床的検討. 胆と膵 $16: 771-775,1995$

4) Lillemoe KD, Pitt HA, Cameron JL: Current management of benign bile duct strictures. Adv Surg 25:119-174, 1992

5) Pitt HA, Miyamoto T, Parapatis SK, et al: Factors influenceing outcome in patients with postoperative biliary strictures. Am J Surg $144: 14-21,1982$

6) Bayar S, Saxena R, Salem RR : Foreign body reaction to a metal clip causing a benign bile duct stricture 16 years after open cholecystecomy : report of a case. Surg Today $30: 537$ $-540,2000$

7) 原均, 磯崎博司, 森田真照他：肝内胆管癌と の鑑別が困難であった良性胆管狭窗の 2 例. 胆と 膵 $19: 851-856,1998$

8）中山雅樹, 㐘池英亮, 栗山茂樹他: 総胆管良性腫 瘍 (Adenomyomatous hyperplasia) の 1 例. 胆 道 $2: 96-100,1988$

9）露口利夫, 斎藤雅彦, 土屋正一他：IDUSによる胆 管狭窟の彭断一良悪性の鑑別一.胆と脺 $18: 139$ $-143,1997$

10) Joske RA, Finlay-Jones LR: Amputation neuroma of the cystic duct stump. Br J Surg $53: 766-768,1966$

11）平野 誠, 宇野雄祐, 村上 望他：腹腔鏡下胆旁 摘出術後, 止血クリップが原因で発症したと考え られる良性胆道狭窄の 1 例. 胆と脺 21 ：913一 917, 2000

12）板棉浩一，佐藤幸一，立石 晋他：下部胆管瘦と 鑑別が困難であった過形成による良性胆道㹨窄の 1 例. 日臨外会誌 $58: 1607-1611,1997$

13) Carroll KM, Sairam K, Olliff SP, et al: Case report: paravesical suture granuloma resembling bladder carcinoma on CT scanning. $\mathrm{Br} \mathrm{J}$ Radiol 69 : 476-478, 1996 
14) Manor A, Kaffe I: Unusual foreign body reac. tion to a braided silk suture : a case report. J Periodontol $53: 86-88,1982$

15) Pecha RE, Prindiville T, Kotfila R, et al : Gas- trointestinal hemorrhage consequent to foreign body reaction to silk sutures: case series and review. Gastrointest Endosc $48: 299-301,1998$

\title{
BENIGN BILIARY STRICTURE CAUSED BY A GRANULOMA GROWING AROUND A LIGATURE OF THE CYSTIC DUCT 23 YEARS AFTER OPEN CHOLECYSTECTOMY
}

\author{
Tsunekazu MIZUSHIMA, Yuko YAMAGAMI*, Yasuyuki KAI* and Kiyoshi YOSHIKAWA* \\ Department of Surgery, Osaka University Graduate School of Medicine \\ - Department of Surgery, Osaka Rosai Hospital
}

We present a rare case of foreign body reaction to a ligature causing benign biliary stricture. A 65year-old man admitted to another hospital because of jaundice and appetite loss and pointed out a high level of serum total bilirubin in February 1997 was referred to the hospital for further examination. He had a past history of undergoing an open cholecystecomy for cholelithiasis in 1974. After admission to the hospital, an abdominal ultrasonography and an abdominal CT scan showed a dilatation of the intrahepatic bile ducts and a hilar mass, suggesting a possible diagnosis of bile duct cancer. The patient underwent a laparotomy, the findings of which revealed a hard mass $1.5 \mathrm{~cm}$ in diameter at the hepatic hilus. A resection of the hilar mass including the left lobe of the liver and common bile duct was performed, followed by a hepaticojejunostomy to the right hepatic duct. A pathologic examination of the specimen revealed a granuloma growing around a ligature of the cystic duct. 